\title{
Lean Supply Chain and Performance Enablers at Homa Lime Company
}

\author{
Odhiambo Hellen Achieng, Wainaina Githii, Ogoro Thomas Ombati \\ Department of Management Science, School of Business, University of Nairobi, Nairobi, Kenya \\ Email: thomasombati@uonbi.ac.ke
}

How to cite this paper: Achieng, O.H., Githii, W. and Ombati, O.T. (2018) Lean Supply Chain and Performance Enablers at Homa Lime Company. American Journal of Industrial and Business Management, 8, 1157-1171.

https://doi.org/10.4236/ajibm.2018.85080

Received: March 31, 2018

Accepted: May 13, 2018

Published: May 16, 2018

Copyright $\odot 2018$ by authors and Scientific Research Publishing Inc. This work is licensed under the Creative Commons Attribution International License (CC BY 4.0).

http://creativecommons.org/licenses/by/4.0/

\begin{abstract}
The business environment has become competitive in the recent past, many companies discover that they need to apt their game in order to remain competitive and continue to be relevant in business. The purpose of the study was to identify the Lean Supply Chain Management activities applied at Homa Lime Company and to find out benefits of practicing Lean Supply Chain Management at Homa Lime Company. The study adopted a case study research design. Primary data was collected through face-to-face interviews by use of interview guide. Secondary data was also used. It included information from archival sources like published reports and journals magazines in order to help the research achieve reliability of the information captured through triangulation. The study established that, LSCM practice, lean procurement, lean supply, lean transportation, lean manufacturing and lean warehousing are the performance enablers at Homa Lime Company.
\end{abstract}

\section{Keywords}

Lean, Enablers, Organisational Performance, Homa Lime Company

\section{Introduction}

Lean Supply Chain Management (LSCM) is the management of a set of organizations linked directly by downstream and upstream flows of products, services, information and finances that work together to reduce cost in production and reduce waste incurred during production, by efficiently and effectively coming up with products that meet the needs of customers [1]. Lean supply chain necessitates that supply chains minimize the cost of operation at all production levels. This requires that supply chain uses the least amount of resources to complete the job. A well-managed supply chain management practice will have lean procurement, lean supply, lean transport, lean manufacturing and finally lean wa- 
rehousing. A lean design will not engage secondary suppliers-a second tier of supplier is expensive to maintain. All these factors when put into practice will reduce the cost of the supply chain operations thus making it cost efficient in the long run [2].

In the $20^{\text {th }}$ century, lean production was liable for the major changes experienced in the production paradigm. The concept involved development of continuous flow of value to remove waste from production processes. It was adopted from Toyota Production System (TPS) whose concern is to bring down or remove waste [2]. Lean production is a new method of manufacturing that gives a better way of management, especially in managing company interactions with its customers and the public, management of product development, production operations and proper resource management. Lean method can be realistic in the supply chain and this can lead to reduction of company losses by business partners [1].

Lean Supply Chain Management (LSCM) practices are significant to organizational performance because it improves the relationship between suppliers and organization which results in delivery of the best value to the customer at affordable cost. It bridges the gap between the customer relationship manager and the supply chain manager. LSCM leads to delivery of best value thus creating good reputation of the firm in terms of overall value creation. It enables the firm to implement and integrate marketing and LSCM which boosts firm image.

Organizational performance consists of actual results of an organization as measured against its intended objectives. This is a concept that deals with, how well the organization can realize its set objectives and achieve its financial ambitions [3]. Short term intention of lean supply chain management (LSCM) practice is basically to increase the production and reduce cost as well as lead time. Contrary, long term intention of lean supply chain is to maximize return on investment for shareholders and to increase market share and profits for all members of the supply chain management.

Key Performance Indicators (KPI) of organizations are methods used to define and assess performance of an organization and evaluate its success. This considers the flexibility of the processes used, quality of products produced, resources utilization and customer satisfaction. KPI must have set standards like ownership, fairness, and achievability. For an organization to achieve required performance, employees must have a say in setting targets. These targets must be clear, realistic, specific, representative, and timely [4]. Any organizational initiative, including supply chain management should eventually lead to peak organizational performance [3].

The major role of organizational performance is to come up with achievable objectives and keep to them; to provide values for evaluation that will ensure customer satisfaction, quality products, proper resources utilization and flexible processes are put in place. Organizational performance empowers the organization to Plan-do-Check-Act (PDCA) when formulating the direction of the strategic activities (Vision, Mission and Core Values). 
It is very vital to know organization's strengths and weaknesses, opportunities and threats for the performance to be achieved. PDCA role can be seen in product quality and continuous improvement in production. Organizational performance is used as a tool to communicate strategic priorities, direction, monitor and enable follow up on the organizations' strategy implementation. Organization performance categorically makes clear the link between performance of sub-units and general organization performance, performance of sub-units and individual employees. It also promotes integration of organization processes by facilitating organizational learning through focusing on change management efforts.

The study looked at the performance measures in relation to Balance Score Card (BSC) approach. Limitations of financial measurement of an organizations short term strategies is recognized by the score card. The balance score card has several measurement perspectives, with the original scorecard having financial, customer, internal business, innovation and learning perspectives. BSC is a key output from the strategy formulation processes, this also include financial and non-financial results, customer results, employee results and societal results. The balance score card is the most used performance measure by most organizations [5].

Performance Prism is a performance measurement model that considers all organization stakeholders, without necessarily focusing on one single group. The organization considers stakeholders needs and wants from the organization and subsequently what the organization wants from its stakeholders. There are five sides to the performance prism strategies; -what strategies does, what organization needs to satisfy the stakeholders needs, processes that are necessary to execute organization strategies, capabilities needed to put in place to allow operation, maintain and improve the processes, stakeholder's satisfaction identify stake holders and their need, and what contribution needed from the stakeholders to maintain and develop capabilities [3].

Activity Based Costing (ABC) is a performance model used to define activities in an organization and assign the cost of each activity with resources to all products and services according to the actual consumption by each activity. The model assigns more indirect (overhead) costs into direct costs.

\section{Literature Review}

Lean Supply Chain Management practices is a concept that looks at how to meet customer needs by giving quality products or services at the right time, right quantity, at the right place by use of minimum resources available and by eliminating waste in the manufacturing process as well as embracing best practices in manufacturing processes [6]. Lean supply is a method that ensures proper use of organizations resources by ensuring work is done correctly with minimal wastage, ensuring all processes that don't add value to the firm during processing of products are removed, to enable customer satisfaction. 
The process of producing what is required by doing away with all the practices that do not add value to the product was first done in Japan by a company called Toyota, popularly known as Toyota Production System by then [7]. After a period of time, Toyota Production System (TPS) was not able to cope with the mass production which was practiced by United States car manufacturers. Due to the challenge of mass production, Toyota decided not to consider practicing mass production like others but decided to focus on reduction of waste in its manufacturing processes [7].

After TPS focused on reduction of waste, lean manufacturing has become more popular in many manufacturing companies around the world. The concept of waste management has spread widely since then [8]. To date, lean manufacturing is perceived to be the leading model in manufacturing.

Time and total quality management and lean procurement is perceived differently amongst different organizations. They explain that lean procurement can be considered as a technique or work culture. [9] states that to make lean procurement successful, members of the supply chain are expected to be reliable and show commitment in the whole process.

Lean procurement principles as the purchase of raw materials in the right quantity and delivered at the right time [10]. He further explains that, buyers in the lean systems are more flexible when designing item specifications and information is freely shared among the members.

Lean supply is a concept behind delivery of raw materials at the time when required for production such that there is no wastage incurred while waiting for production to take place. This reduces the cost of inventory storage in the organization thus leading to less lead times. There is need to establish criteria to assess, evaluate and re-evaluate suppliers and this should be maintained to ensure the supply remains lean. There are reasons for evaluating suppliers. When a firm identifies a supplier to provide a new product, suitability checks must be done whether the supplier firms are ISO accredited or not. To know cost, a supplier who knows it is under assessment will often be inspired to improve its price to ensure it remain in business. Compliance-if the supplier is not compliant, then the knowledge that assessment is underway will provide the supplier to become compliant. Quality and lead time are major performance indicators that suppliers can be encouraged to improve on when knowing constant assessment takes place [10].

According to [11], the concept of lean when applied in transport brings benefits to the organization. In transportation for instance, exists a significant waste and unnecessary costs that are incurred. In the recent times, customers acknowledge about the value of transportation added to the supply chain management and this is resulting in one of the differentiating factors in the global market.

The concept of lean transportation as a component of lean supply chain management has four lean transportation laws which influence of lean transportation on the Organizational performance of an organization. These laws include the 
law of daily event management, the law of transportation waste, the law of transportation performance as well as the law of transportation strategy [12].

Lean manufacturing provides an alternative to the traditional manufacturing. Several benefits have been realized by organizations that have applied lean manufacturing including increased quality time, reduced waste of materials, reduced lead times. The principles of lean manufacturing are relevant in all the companies across the global market [13]. In order to achieve lean manufacturing, waste has to be eliminated from the system. It also stresses the need to make manufacturing activities flow directly towards the customer. Lean manufacturing shows how organizations can achieve performance due to their commitment on improving flow of material and information among all the business functions [13].

Lean warehousing is an important component of lean supply chain management practices. It is very instrumental in the distribution area to improve on productivity and meet the increasing demands of the customer, reduce waste, breaks bulk of some items by re-packaging utilization of the available space by proper arrangement of products [14].

According to [14] warehouse comes down to two things: the management of space and time. They further added that the warehouse can be used to manage the freight costs in the environment and it is also used to deliver and improve on customer service. According to [15] for organizations to maximize the value of lean warehousing they need to adopt lean distribution.

Organizational performance viewed based on the Porter's value chain model, explain that organizations activities can be classified into five primary and four support activities. The four support activities lead to firm performance, firm infrastructure, product cost, organization safety and security thus improving firm performance. Organizations with better performance are perceived to have improved customer satisfaction, quality goods and services, reduced waste and inventory with consequential reduced costs, improved productivity, reduced product development time, increased flexibility in meeting market demands, reduced work-in-progress, improved customer service and delivery times and finally better utilization of resources [3].

\section{Statement of the Problem}

Finding new ways of service delivery and adding value to customers with minimum cost has become a major challenge to organizations. Uplift customer value through customer satisfaction by providing quality products in the supply chain has become a challenge too. Companies experience increased customer demands on value and quality, reduction in cost and fast operation. The organizations strive to maintain low inventory in warehouses to reduce cost and increase profitability for organization's [15].

Internal factors such as target costing, use of value engineering, use of cross functional teams, just in time operation (JIT) and zero defective products, customer lead times, specification demands, product variety, product life cycle, timely orders and deliveries, and effective distribution has led to the need for 
lean supply chain management practice [3] [15].

Supply chain responsiveness relates directly with business performance, increases revenues, lower costs, leads to customer satisfaction and loyalty hence increased profits in the long-run and thus motivates both researchers and practitioners to explore the area [16]. [6] did a research on lean supply chain practices and performance in the context of Malaysia and found out that lean supply chain practices are directly related to the performance of electronics manufacturing companies in Malaysia; [16] studied the relationship between supply chain performance and supply chain responsiveness in supermarkets in Nairobi and found out that supply chain performance and supply responsiveness, reliability and flexibility indicate very strong relationship with supply chain performance.

While [17] did the application of lean thinking to business process management and found out that lean management and application of related tools, equipment and techniques is a continuous process at Kenya Revenue Authority highly driven by the need to improve service delivery; [18] on supply chain management strategies and performance of commercial entities, observed that organizations in Kenya were yet to fully embrace the supply chain management strategies and most of the practices used were borrowed from the procurement philosophy.

The research aimed at studying the totality of lean practices: lean procurement, lean supply, lean transportation, lean manufacturing, lean warehousing and their effects to organizational performance. No study has addressed the five leans practices together in relation to flexibility of manufacturing process, product quality, resources utilization and customer satisfaction. The research therefore, aims to fill this gap.

\section{Objectives of the Study}

To identify the Lean Supply Chain Management practices applied at Homa Lime Company and to find out benefits of practicing Lean Supply Chain Management at Homa Lime Company.

\section{Methodology}

Researcher used a case study design because the study research questions, focused mainly on how and why. A case study research explores a specific situation by giving in-depth information about the issue at hand in a real-world context [19]. When there is a gap in existing theory, case studies help researchers to have a clear focus to collect specific data in a systematic manner [20]. This research identified a gap because, none of the studies have looked at lean transport, lean warehousing, lean supply and lean manufacturing together and how they affect organization performance in terms of flexibility of processes in the organization, product quality, how resources are utilized and in terms of customer satisfaction. 
Case studies benefits from the prior development of theoretical propositions to guide data collection and analysis as they can be conducted and written with many different motives including the simple presentation of individual cases or the desire to arrive at broad generalizations based on case study evidence. [21] is an exemplary of successful well-done case studies: he has done several meaningful case studies that can be used as point of reference.

Case studies have challenges on how to present the research outcomes, how to draw and validate conclusions from data analysis. To mitigate this, the researcher presented a detailed narrative supported by quotations from key respondents and other forms of evidence [22].

\subsection{Data Analysis and Interpretation}

The research aimed at studying the Lean Supply Chain Management practices applied at Homa Lime Company and to find out benefits of practicing Lean Supply Chain Management at Homa Lime Company. Findings are hereby presented below.

\subsection{Lean Procurement}

From the findings, lean procurement is practiced by Homa Lime Company evidenced by the way the tendering process is done-prequalification of suppliers, proper records by clerks to ensure procurement is easy to follow in terms of quantity, delivery time and specifications of the raw materials confirmed.

... Supplies are supplied in time without delays, before supplies are awarded tenders they are subjected to supplier pre-qualification test and only those who meet the company's requirements get the tender ... When there is a shortage of raw materials, the company goes for direct procurement (Suppliers Officer, Homa Lime Company).

\subsection{Lean Supply}

Lean supplier is practiced at Homa Lime Company. Supplies bring raw materials when they are given the tender. The firm uses different supplier at different times depending on which supplier meets the prequalification. Sometimes the prequalifying team settles on the lowest bidder considering the quality of raw materials and not just the price quoted.

... Sometimes the supplies don't follow to the letter, the organizations raw materials specifications, more often than not this had led to our firm accepting supplies that sometimes don't meet all the stated specification ... We would want production to be continuous so we receive the supplies in their state and complains can be made thereafter (Warehouse Manager, Homa Lime Company).

\subsection{Lean Transportation}

The company practices lean transportation; it has outsourced transport services 
despite having company vehicles. When there is a breakdown of any vehicle on transit there will be a vehicle on standby to take over and deliver products. The company has outsourced twenty-nine (29) different companies that assist in its transportation of finished products to the customers.

.... We ensure transportation of finished product is not challenged, we have outsourced transport services from twenty-nine companies to ensure no breakdown interferes with the transport system schedules (Transport Manager, Homa Lime Company).

When the business was started, the company purely used its transport fleet to transport finished products. Due to the many challenges that were experienced, there were times the vehicles ferrying milk to Kisumu would take two days on the road due to break down, by the time the milk got to Kisumu, we would sell the milk and the next day all customers would bring the milk requesting for replacement.

The company would compensate for the spoilt milk which resulted in the company making losses. Most of our perishable products got spoilt on the road due to bad weather or mechanical breakdown, though they still needed to be in business and make profits, so that was the genesis of thinking about lean transportation to avoid the wastages. The company decided to outsource transport services.

\subsection{Lean Manufacturing}

The organization uses materials on arrival. Once the raw materials are delivered they are recorded and processed on first come first processed basis. Proper records are maintained by the factory clerks in terms of quantity of raw materials that are received and in terms of total output from the raw materials out of the factory.

... Use of modern technology in processing of raw materials thus eliminating most of the process that do not add value during production ... Flexi work times and flexi plants have made it easy to produce products and store in the warehouse (Warehouse Manager, Homa Lime Company).

The factory clerks ensure raw materials are recorded-the number of tons received for production each day. They ensure the numbers of tons produced are recorded both by the factory clerks and the warehouse clerks for consistency, such that input and output can easily be monitored. This has enabled the practice of lean production.

Two major services to improve manufacturing processes have been put in place that is, cleaning services and transport services. Table 1 clearly shows the services that have been outsourced for the last two years.

\subsection{Lean Warehousing}

The firm has put in place three major warehousing-One responsible for the 
Table 1. List of out-sourced services.

\begin{tabular}{ccc}
\hline Year & 2016 & 2017 \\
\hline Out-sourced services & Transportation & Transportation \\
& Cleaning services & Cleaning services \\
\hline
\end{tabular}

Source: Homa lime report, 2017.

machine spare parts, the other used for food products and the third one used for chemical products to avoid any product contamination at the warehouse. The ware house is also used for product packaging and assembling. The warehouse staffs are responsible for disposal of expired products and defective products that cannot be reposed. The disposal is done under the procurement and disposal act 2015.

... There are three major warehouses, for machine spare parts, food products and chemicals products... The warehouse does cross-docking, trucks deliver goods to the facility and then they are broken into smaller lots and finally products loaded onto trucks (Warehouse Manager, Homa Lime Company).

The warehouse uses the latest trends of storage it has the cold storage for perishable products, it has a store for chemicals and a store for spare parts to ensure contamination of products is controlled. All the different types of products needed to perform a particular job are stored together.

Breaking of the bulk, re-packaging and labeling are done in the warehouse. The warehouse is located next to the factory for ease of loading and offloading of products to the factory. The warehouse stores are labeled as Store 1, Store 2 and Store 3 to avoid confusion during storage. Table 2 illustrates that.

\subsection{Flexibility of Processes}

The use of Supply Chain Management Practices at Homa Lime Company, affected positively the flexibility of the processes at therein. Homa Lime uses the flexi plants the factory walls are movable and the size of the factory can easily be adjusted according to the immediate need. The factory workers work in shifts both day and night and when a staff is not able to report on duty any worker can replace them. There is a schedule for emergencies, in case a worker is not able to report on duty, the replacement is easily obtained because workers are trained in such a way that they have multiple skills and can switch from one task to another comfortably.

The manufacturing processes are able to over process and store during seasons that raw materials are produced in abundance and manufacture enough, when the materials are not in season without supplies to the market being affected. The factory easily changes to produce another product line when there be need to do so. The Warehouses are able to store chemicals, spare parts, and food products in all quantities, when one quantity goes down and the other goes up, the adjustable walls are adjusted accordingly. This clearly demonstrated flexibility. This is illustrated in Table 3. 
Table 2. Warehousing storage guide.

\begin{tabular}{cccc}
\hline Name of stores & Store 1 & Store 2 & Store 3 \\
\hline Type of products & Machine spare parts & Chemical products & Food products \\
\hline Source: Homa lime report, 2017. & &
\end{tabular}

Table 3. Supply chain management practices and flexibility.

\begin{tabular}{cl}
\hline $\begin{array}{c}\text { Supply chain management practices } \\
\text { Lean procurement }\end{array}$ & $\begin{array}{l}\text { Areas of flexibility } \\
\text { easily adapt to change }\end{array}$ \\
\hline Lean transportation & $\begin{array}{l}\text { Uses outsourced transport system and use of } \\
\text { modern transport systems }\end{array}$ \\
Lean manufacturing & $\begin{array}{l}\text { Flexi plants, Flexi manufacturing processes } \\
\text { Use of flexi work times }\end{array}$ \\
Lean warehousing & $\begin{array}{l}\text { Warehouse able to store chemical, food and spare } \\
\text { parts without contamination }\end{array}$ \\
Lean supply & $\begin{array}{l}\text { Supply of variety of raw materials both when } \\
\text { materials are in season or not }\end{array}$ \\
\hline
\end{tabular}

Source: Researcher, 2017.

... We have a flexible plant, which has the zero-changeover time plant using movable equipment, knockdown walls and easily accessible and re-rotatable, easily adapt to change, we have Flexible processes, flexible manufacturing systems, easy to set up equipment's ... Production technological approaches we use allow rapid low cost switching from one product line to another ... (Head of Operations, Homa Lime Company).

\subsection{Product Quality}

All the products met the quality standards set by the organization. This was evidenced by customer's feed-back analysis. Quality was not compromised the research revealed. Sometimes products were recalled due to failure of meeting quality standards and taken back to the factory for re-processing.

... Quality Assurance Department deals with testing of product quality to ensure the products meet the set standards of quality of the firm ... Defective products returned by the customers, once received, we take them back to the plant for repossessing and compensation given to the customer either monitory or replacements of products which ever the customer finds convenient at that particular time. We give our apologies and explain further to the customer the new products in the market (Quality Manager, Homa Lime Company).

Moreover, defective products are recycled while expired products are recalled from the market and disposed of in line with the Procurement and Disposal Act 2015. The organization keeps the record of all the complaints received from 
customers, does customer complains analysis then customers are given feedback to the complaints within three days.

Customer complaints are handled by the Public Relations Office, though the feedback is communicated to the affected customers through the Human Resource Department. When a customer fails to get feedback in time, the inquiries are made at Human Resources Department, who will in return find out from the Public relations office why the communication has not been done and the way forwards that needs to be taken. This is further explained in Table 4 .

The firm came up with the following measures to ensure they achieve the required product quality in future and meet customer satisfaction. This decision was made as a way that would minimize or stop the production of defective products. Customers having returned defective products to the firm left managers working hard on ways to ensure there is no wastage during production and at the same time no defective products produced.

... Award of Suppliers tender will be on quality merit and not on low bidder get it principle as we practiced before, staffs with relevant knowledge, skill and experience will be employed ... Product inspection will be done at every level of production stage instead of waiting to do quality assurance test on completed products (Procurement Manager, Homa Lime Company).

\subsection{Resource Utilization}

The study revealed organization resources were properly utilized, systems were in place to ensure no wastage incurred, every worker was accountable for the machines under their custody, latest technology in processing were used in the company, there were clerks responsible for recording raw materials that were brought into the production unit and the total output from the factory thus ensuring optimization in resource utilization and accountability.

... We ensure raw materials are used as scheduled, all purchases done according to the Procurement Plan, production is done using latest technology which minimizes waste and reduces lead times ... We are in collaboration with transport organizations to increase productivity and reduce on cost in terms of product distribution to markets, fuel millage is taken weekly to confirm distance covered, fuel used and the accountability lies with the drivers (Transport Manager, Homa Lime Company).

The company has in place a system that monitors how resources are used, the head of departments are responsible for the machines used by the workers in their department. Any misuse that occurs during the use of the company

Table 4. Number of complaints received.

\begin{tabular}{ccccccc}
\hline Year & 2012 & 2013 & 2014 & 2015 & 2016 & 2017 \\
\hline No of complains & 30 & 20 & 33 & 14 & 10 & 8 \\
\hline
\end{tabular}

Source: Homa lime report, 2017. 
properties is charged on the personnel who are involved. A salary of staff is attached if the company proves beyond reasonable doubt that the machine got spoiled as a result of mismanagement.

The heads of departments have a duty to report to the Human Resource Manager any machine that shows signs of not working well, such that maintenance is sought in good time to repair the damages rather than waiting until the machine cannot work which would mean buying a new machine. Table 5 shows the accountability list showing who is responsible for what?

\subsection{Customer Satisfaction}

Customers are satisfied with the products and services they get from the company. This is concluded from the customer feedback to the company in public relations department through human resource department, complaints/compliments received are analyzed and feedback given back to the customers. Most orders received by the marketing department are through referrals from previous customers' evidence customer satisfaction.

... Customers are satisfied as evidenced by the customer loyalty, customers coming back for the products, the product order levels have gone up year by year due to customer referrals ... The company set objectives on customer satisfaction has been met and this has created peaceful coexistence with the locals (Marketing Manager, Homa Lime Company).

The product order levels have gone up as a result of customer referrals. Marketing Principles explain that a satisfied customer will bring more customers to the company and at the same time dissatisfied customers may send too many potential customers away. The company receives more compliments through the office hotline and email given to the public more that the complaints from customers.

The company has achieved its objectives in terms of product sales. It surpassed the sales target making the company make profit-part of the profit is used by the company by giving back to the community that gave it land. The company has used the extra profits to build churches, schools and given bursary to poor children from the locality.

The company enjoys a peaceful existence with the locals unlike some companies are permanently at war with the locals. Customer Satisfaction rate keep on going up yearly same to the product order levels by the customers. Table 6 illustrates this.

Table 5. Homa lime resources accountability list.

\begin{tabular}{cccccc}
\hline Resources & $\begin{array}{c}\text { Factory } \\
\text { machines }\end{array}$ & $\begin{array}{c}\text { Raw } \\
\text { materials }\end{array}$ & Staffs & $\begin{array}{c}\text { Company } \\
\text { vehicles }\end{array}$ & $\begin{array}{c}\text { Manufactured } \\
\text { products }\end{array}$ \\
\hline Accountability & $\begin{array}{c}\text { Operations } \\
\text { manager }\end{array}$ & $\begin{array}{c}\text { Supplies } \\
\text { manager }\end{array}$ & $\begin{array}{c}\text { HRM } \\
\text { manager }\end{array}$ & $\begin{array}{c}\text { Transport } \\
\text { manager }\end{array}$ & $\begin{array}{c}\text { Warehouse } \\
\text { manager }\end{array}$ \\
\hline
\end{tabular}

Source: Homa lime report, 2017. 
Table 6. Customer satisfaction report on product \& customer order levels.

\begin{tabular}{cccccc}
\hline Year & 2013 & 2014 & 2015 & 2016 & 2017 \\
\hline Satisfaction \% & 58 & 64 & 79 & 87 & 85 \\
Order levels \% & 60 & 73 & 75 & 79 & 80 \\
\hline
\end{tabular}

Source: Homa lime report, 2017.

\section{Study Discussions}

The study has revealed all the five Lean Supply Chain Management Practices are practiced at Homa Lime. There is a strong correlation between practicing LSCM practices and achieving organizational performance. The study has achieved its objective of identifying LSCM practices embraced by the firm and the benefits driven from practicing LSCM as, flexibility of processes, quality products, proper resource utilization and customer satisfaction.

According to [8] lean supply is a method that ensures proper use of organization resources. Homa Lime organization resources are properly used and accountability check system is put in place to reprimand any wastage by any worker at all stages (Table 6). According to [16], to make lean procurement successful, members of the supply chain are expected to be reliable and show commitment in the whole process. At Homa Lime, members of the supply chain showed commitment by production unit showing the ability to increase or decrease production as need arises. Transportation systems were in check with the company outsourcing twenty-nine companies for its transportation of finished products from the factory, the firm put in place flexi plants, flexi processing methods and adopted the flexi work system which ensures commitment by all staffs is achieved. Their warehousing system uses the latest technology and is designed in such a way that no contamination occurs at the warehouse. Supplies manager ensures supplies are in place both during season and off season of the raw materials.

The study has confirmed chemical industries can be set up in very remote undeveloped environments and leads to the environment opening up and makes it an economic bay. This can be seen on how Homa Lime operated in different product lines and has attracted tourists in the area.

\subsection{Analysis and Interpretations}

From the study findings, it is important for firms to practice Lean Supply Chain Management. It brings a lot of benefits to the organization which eventually improves on organizational performances. It leads to continuous improvement of firm's products in terms of quality, availability and flexible market distribution of products, and as well contributed in the many product lines marketed by Homa Lime Company. Practicing LSCM motivates team work in the organization, all the departments need each other in achieving Organizational objectives, it also promotes professionalism, when individuals have targets to meet it, reduces staff absenteeism, laziness because all individuals will strive to achieve 
their targets to remain relevant in their various departments as well as in the organization.

\subsection{Conclusions}

Homa Lime Company practices all the five-major lean supply chain management practices though varying capacities. In reference to the findings, the study concluded that the adoption of lean supply chain management practices improved the organizational performance resulting in flexible processes, quality products, proper resource utilization and customer satisfaction.

\subsection{Recommendations}

With the growth and introduction of internet in the county as a result of fiber cable, the study recommends e-commerce to be used in transactions and online security measures to be put in place. Homa Lime Company does not embrace technology by using online transaction, which is a powerful business tool in the modern business world.

The study recommends that further research be undertaken to look at lean supply chain management practices, Green Supply Chain and e-commerce at Homa Lime Company because it's a chemical manufacturing company and there is need to look at how it conserves the environment in terms of chemical products disposal.

\subsection{Limitations of the Study}

The study was faced with bad weather as a result of too much rainfall in that region. This made accessibility a major problem. There was also political unrest in the region, political demonstrations and economic boycott which interfered with communication and transport. Due to this, interview dates had to be rescheduled twice. This made the study expensive in terms of transportation cost and accommodation.

The study experienced contextual limitation because it was only conducted within Homa Lime Company the findings are confined to Homa Lime Company and cannot therefore be generalized to represent the manufacturing sector.

\section{References}

[1] Womack, J.P. and Jones, D.T. (2007) Lean Thinking: Banish Waste and Create Wealth in Your Corporation. Simon and Schuster, New York, NY.

[2] Agarwal, A. and Shankar, R. (2006) Analyzing Alternatives for Improvement in Supply Chain Performance. Work Study, 51, 32-37. https://doi.org/10.1108/00438020210415497

[3] Lysons, K. and Farrington, B. (2006) Purchasing and Supply Chain Management. Pearson Education, London.

[4] Taylor, C. and Fitz-Gibbon (1990) Performance Indicators.

[5] Kaplan, R.S. and Norton, D.P. (2001) Transforming the Balanced Scorecard from Performance Measurement to Strategic Management: Part 1. 
[6] Daudi, A. and Zailani, S. (2011) Lean Supply Chain Practices and Performance in the Context of Malaysia. http://www.Intechopen.com

[7] Herron, C. and Hicks, C. (2008) The Transfer of Selected Lean Manufacturing Techniques from Japanese Automotive Manufacturing into General Manufacturing (UK) through Change Agents. Robotics and Computer-Integrated Manufacturing, 24, 524-531. https://doi.org/10.1016/j.rcim.2007.07.014

[8] Chauhan, G. and Singh, T.P. (2012) Measuring Parameters of Lean Manufacturing Realization. Measuring Business Excellence, 16, 57-71. https://doi.org/10.1108/13683041211257411

[9] Puschmann, T. and Alt, R. (2005) Successful Use of E-Procurement in Supply Chains. Supply Chain Management. An International Journal, 10, 122-133. https://doi.org/10.1108/13598540510589197

[10] Ellram, L.M. (1995) Total Cost of Ownership: An Analysis Approach for Purchasing. International Journal of Physical Distribution \& Logistics Management, 25, 4-23. https://doi.org/10.1108/09600039510099928

[11] Villarreal, B., Garcia, D. and Rosas, I. (2009) Eliminating Transportation Waste in Food Distribution: A Case Study. Transportation Journal, 48, 72-77.

[12] Hines, P. and Taylor, D. (2000) Going Lean. Lean Enterprise Research Centre Cardiff Business School, Cardiff, UK, 3-43.

[13] Womack, J.P., Jones, D.T. and Roos, D. (1990) The Machine that Changed the World: The Story of Lean Production. How Japan's Secret Weapon in the Global Auto Wars Will Revolutionize Western Industry Rawson Associates, New York, NY.

[14] Ackerman, K.B. (2007) Fundamentals of Supply Chain Management: An Essential Guide for 21st Century Managers. DC Velocity Books.

[15] Holweng, M. (2013) Creating the Customer Responsive Supply Chain; A Reconciliation of Concepts. Journal of Operations and Production Management, 27, 1144-1172.

[16] Mageto, J.N. (2009) Relationship between Supply Chain Performance and Supply Chain Responsiveness: A Case of Supermarkets in Nairobi, Kenya. Unpublished MBA Thesis, University of Nairobi, Nairobi, Kenya, 58.

[17] Karoki (2014) Outsourcing of Human Resource Management Functions Services by the Public Service in Kenya. Unpublished MBA Project, University of Nairobi, Nairobi.

[18] Wainaina (2009) Supply Chain Management Practices and Performance in Cement in Cement Industry in Kenya. Unpublished MBA Project, University of Nairobi, Nairobi.

[19] Benbasat, I., Goldstein, D.K. and Mead, M. (1987) The Case Research Strategy in Studies in Information Systems.

[20] Mintzberg, H. (1979) An Emerging Strategy of "Direct" Research. Administrative Science Quarterly, 24, 580-589. https://doi.org/10.2307/2392364

[21] Yin, R.K. (1984) Case Study Research: Design and Methods. Newbury Park, CA.

[22] Yin, R.K. (1989) Yin Case Study Research. Design and Methods. 3rd Edition, Sage Publications, Thousand Oaks. 